\title{
Highway Emergency Response and Accident Mitigation Service (HERAM) - A Field Report
}

\author{
Balaji Utla*, Dr. Shailendra Kumar B. Hegde, Dr. Sri Ranga Prasad Saride, Dr. \\ Ramanuja Chary Kandaala, Mr. Sridhar Upadhya and Anukrati Saxena
}

Piramal Swasthya Management and Research Institute, Hyderabad, India

\section{Objective}

The objectives of this paper are

1. To describe the functioning of a highway emergency response and accident mitigation service and

2. To characterize the profile of the accidents and the victims served by this project

\section{Introduction}

The increasing frequency and severity of Road Traffic Accidents (RTA) in India have caused grave concern for road safety, posing serious challenge to transport policy makers, planners, regulators, police, engineers and civil society alike. With just $1 \%$ of world's vehicles, India leads with $10 \%$ of world's total Road Traffic Fatalities, resulting in untold misery to lakhs of people and costing about $3 \%$ of the GDP ${ }^{1}$. Due to the impact of the RTA, the United Nations declared the current decade "the decade of action for road safety with a goal to save five million lives"2. Post-crash response is very critical to reduce the mortality and morbidity due to accidents.

Piramal Swasthya in collaboration with the National Highways Authority of India and General Insurance Company set up the Highway Emergency Response and Accident Mitigation Service between Hyderabad and Vijayawada, as a pilot project to address the post-crash response.

\section{Methods}

We report a descriptive cross-sectional analysis of data pertaining to accidents that occurred on the stretch mentioned above, over a period of one year from June $1^{\text {st }} 2014$ to $30^{\text {th }}$ May 2015. Any RTA on this stretch could be reported by calling 1033. and all such calls were attended by a trained individual at a $24 \times 7$ central 4 -seater call center. A fully equipped trauma ambulance was despatched to the site immediately. The victim was attended to by well-trained paramedical workers stationed in the ambulance and then transported to the nearest health care facility.

Information regarding the accident was also transmitted to the nearest police official. Thus the entire service was integrated with the Police at the ground level, thus leading to a very robust network of emergency response. Data were entered on an android based hand held device by a trained paramedic and analysed using descriptive statistics.

\section{Results}

A total of 1379 calls were received reporting a total of 1311 accidents took place in the study period leading to injuries to 1489 people. Of the 1311 accidents, 774 (59.04\%) were attended to by 1033 ambulance. An incoming call was attended within an average of four seconds. On an average, an ambulance was dispatched to the site of accident by one min \& $19 \mathrm{sec}$. More than half the accidents were of the collision variety $(55.42 \%)$ while the non-collision variety contributed about one-fifth of the accidents. Most commonly, accidents took place in the evenings between $4 \mathrm{pm}$ and $8 \mathrm{pm}(24.03 \%)$ followed by those in the afternoon $(20.15 \%)$. The age of the victims ranged from $1 \mathrm{yr}$ to 93 yrs with a mean age of $36.4( \pm 14.6)$ yrs. A majority of the accident victims were males $(83.73 \%)$. More than half the accident victims were between 21 and 40 yrs of age (56.64\%).

\section{Conclusions}

Highway emergency response and accident mitigation service with a dedicated call centre, ambulance and integration with the police force is an effective service to provide post-crash response to accident victims on the National Highway. This service attended to $60 \%$ of the accidents in the service area. Incidence of fatalities was $5.63 \%$. We recommend this service at national level to provide emergency ambulance care service to accident victims on National Highways.

Time taken for specific critical activities after receiving the distress call

\begin{tabular}{|c|c|c|}
\hline Time taken & $\begin{array}{c}\text { Average time taken } \\
\text { (Duration in MM:SS) }\end{array}$ & $\begin{array}{c}\text { Maximum time taken (Duration } \\
\text { in HH:MM:SS) }\end{array}$ \\
\hline To answer an incoming distress call & $00: 04$ & $00: 00: 14$ \\
\hline To dispatch help / ambulance & $01: 19$ & $00: 07: 05$ \\
\hline $\begin{array}{c}\text { To reach the accident site from the time } \\
\text { of answering the call }\end{array}$ & $12: 01$ & $00: 30: 57$ \\
\hline $\begin{array}{c}\text { To reach the hospital from the time of } \\
\text { answering the call }\end{array}$ & $37: 52$ & $01: 12: 05$ \\
\hline $\begin{array}{c}\text { To reach the hospital from the time of } \\
\text { dispatch }\end{array}$ & $36: 35$ & $01: 04: 45$ \\
\hline $\begin{array}{c}\text { To reach the hospital from the accident } \\
\text { site }\end{array}$ & $22: 38$ & $00: 57: 48$ \\
\hline
\end{tabular}

\section{Keywords}

Emergency Response; Accident Mitigation; Ambulance; Call Centre; Road Traffic Injury

\section{Acknowledgments}

We are grateful to all the call centre officials who have been handling all the calls since the inception of the programme. We acknowledge the contributions of the staff members of Piramal Swasthya Management \& Research Institute in helping us complete this paper.

\section{References}

[1] World Health Organization. Global status report on Road Safety 2013 - Supporting a decade of Action. Geneva Switzerland. [cited $22^{\text {nd }}$ July 2015] Available from: http://www.who.int/violence_injury prevention/road safety status/2013/en/

[2] United Nations Road Safety Collaboration. [cited 22 $22^{\text {nd }}$ July 2015] Available from: http://www.who.int/roadsafety/en

*Balaji Utla

E-mail: balaji.utla@piramalswasthya.org 